\title{
The Willingness to Pay for Residential PV Plants in Italy: A Discrete Choice Experiment
}

\author{
Paolo Bragolusi and Chiara D'Alpaos *(D) \\ Department of Civil, Environmental and Architectural Engineering and Interdepartmental Centre “Giorgio Levi \\ Cases", University of Padova, 35131 Padova, Italy; paolo.bragolusi@unipd.it \\ * Correspondence: chiara.dalpaos@unipd.it; Tel.: +39-049-8276717
}

check for updates

Citation: Bragolusi, P.; D'Alpaos, C. The Willingness to Pay for Residential PV Plants in Italy: A Discrete Choice Experiment. Sustainability 2021, 13, 10544. https://doi.org/10.3390/ su131910544

Academic Editor: Gerardo Maria Mauro

Received: 5 August 2021

Accepted: 12 September 2021

Published: 23 September 2021

Publisher's Note: MDPI stays neutral with regard to jurisdictional claims in published maps and institutional affiliations.

Copyright: (c) 2021 by the authors. Licensee MDPI, Basel, Switzerland. This article is an open access article distributed under the terms and conditions of the Creative Commons Attribution (CC BY) license (https:/ / creativecommons.org/licenses/by/ $4.0 /)$.

\begin{abstract}
PV energy generates economic and environmental benefits (e.g., energy cost-saving, GHG emissions reduction, etc.), which can be capitalized into market prices. There is, therefore, growing interest in assessing the value that PV systems add to solar homes (i.e., homes equipped with PV production plants) market prices. Although the number of solar homes has experienced rapid growth in Europe and Italy, literature investigating the impact of PV power plants on home values is still very limited. This paper aims to fill this gap. We implement a Discrete Choice Experiment (DCE) approach to estimate individuals' WTP for different typologies of domestic PV plants, which vary in technical characteristics. Our findings show that homebuyers are willing to pay a price premium for solar homes, ranging from some $3 \%$ to some $15 \%$, depending on PV panels' characteristics. These results can provide a wealth of recommendations to different interested parties such as homeowners, homebuyers, realtors, and governments, seeking knowledge on the capitalization effect of residential PV plants on the housing market to implement cost-effective investment strategies or design optimal policy incentives.
\end{abstract}

Keywords: solar photovoltaic power plants; buildings energy efficiency; discrete choice experiment

\section{Introduction}

During the last decade, the European Union (EU) has enacted directives to reduce greenhouse gas (GHG) emissions through the promotion of renewable energy sources (RES). The first most important directive is the Renewable Energy Directive (Directive 2009/28/EC), which provided a framework for promoting renewable energy production and setting mandatory national targets for the overall share of green energy. In detail, this Directive established that European member states had to achieve a $20 \%$ share of energy from renewable sources in community energy consumption by 2020 (revised upward to $32 \%$ by 2030). In 2018, the Renewable Energy Directive Recast (Directive 2018/2001/EU) was enacted for supporting emissions reduction commitments, which had already been established in the 2015 Paris Climate Agreement of 2015 [1]. Energy production from renewables is a key factor for improving buildings' energy efficiency and decarbonizing the existing building stock in the near future [2]. In this context, electrical energy generation from solar photovoltaic (PV) power plants has grown in the last decades as solar energy is deemed as one of the most promising RES in accelerating the energy transition [3-6]. For years, EU Governments have promoted investments in PV plants due to generous incentive schemes, which turned out to be a key factor in private investors' decisions [7-10]. These incentives proved to be successful in stimulating investments in residential PV plants, which became attractive for households and small private investors [11-13]. Italy is no exception within the EU-27 area. A recent report by the publicly-owned company in charge of promoting, supporting, and developing RES in Italy (GSE) reveals that in 2019 about 880,000 PV plants were operating in Italy ( $+20.7 \%$ compared to 2018$), 82 \%$ of which are residential, and that a $4.6 \%$ increase in PV production was registered in 2019 compared to 2018 [14]. 
Investments in residential PV plants usually aim at improving buildings' energy efficiency and reducing energy costs bills thanks to self-consumption $[4,13,15,16]$. In this respect, academics and practitioners acknowledge that the greater the building energy efficiency, the greater its market value. Therefore, there is growing interest in assessing the value that PV systems add to solar homes (i.e., homes equipped with PV production plants) market prices. Among the wealth of benefits generated by improvements in a building's energy performances, energy cost savings are perceived as of major relevance. Nonetheless, nowadays, due to increased social awareness on climate change effects and environmental concerns, reduction of GHG emissions provided by RES, and solar energy specifically, is assuming an utmost relevance in our society. Consequently, solar homes can be viewed as one of the better-known 'green products' sold in the market [17].

In the last decade, a strand of literature focusing on the economics of green buildings has stepped into academia and is rapidly flourishing at the national and international level [12,18-22]. In addition, some authors have recently focused on the market price premium for green buildings [23-26]. The real estate hedonic literature capitalizes different house characteristics and attributes into property market prices. Although solar installations can be considered a characteristic/attribute, which improves housing quality, and the market for solar homes has grown significantly due to generous incentive schemes paid in the past, there is still limited evidence on the capitalization effect of residential PV plants. Recent contributions in the literature have provided for the US real estate market some estimates of the price premium (i.e., the additional price) for solar homes compared to comparable homes not equipped with PV panels [17,27-31]: according to their findings, solar homes add to home sale transactions from $3-4 \%$ to $17 \%$ of the median home sales price.

Nonetheless, although the number of solar homes has experienced rapid growth in Europe and Italy, literature investigating the impact of PV power plants on EU home values is still very limited $[32,33]$. Thus far, literature has mostly contributed to measuring the market impact of overall buildings efficiency, and there is little information on the market value effect of PV panels' installation. There is indeed a lack of market data on sales transactions of solar homes. As the expected lifespan of a PV system is about 25 years, risk-averse homeowners invest if they expect to own the property during the payback period. Consequently, many solar homes will likely enter the market in the near future [34-36]. The strand of literature investigating the market price premium for solar homes is even more limited concerning the Italian context [12,13]. Market price premiums are usually estimated by implementing hedonic regressions, firstly prosed by [37] Rosen (1974), which are grounded in the availability of datasets that provide home characteristics (e.g., ground floor area, quality of finishes, year built, energy performance certification, distance to the central business district, etc.), including the presence of PV panels and relative market prices. There are no such datasets available in Italy; literature focusing on the market price premium for solar homes is scarce [13]. This paper aims to contribute to this literature and verify whether solar homes add (and how much) to sale transaction prices. Nonetheless, due to the lack mentioned above of market data, it is not currently possible to adopt revealed preference methods, and more specifically, hedonic regressions, to estimate the market price premium for solar homes in Italian real estate markets. Consequently, following [13], who proposed a contingent valuation study based on stated preference data, we determine the general preferences towards solar homes by a discrete choice experiment (DCE) based on responses of 240 homebuyers in Italy. In detail, we estimate individuals' willingness to pay (WTP) for different typologies of residential PV plants, which vary in technical characteristics. As per the knowledge of the authors, this is the second paper, in addition to [13], to estimate the price premium of an installed PV system on a residential property, measured by stated choice data in the Italian housing market, and it is the first implementing a discrete choice experiment. Consequently, it expands existing knowledge for issues of ever-growing interest, such as valuing and measuring preferences for solar homes. Our findings show that homebuyers 
are willing to pay a price premium, ranging from some $3 \%$ to some $15 \%$, depending on PV panels' characteristics. These results can provide a wealth of recommendations to different interested parties such as homeowners, homebuyers, realtors, and governments, seeking knowledge on the capitalization effect of a residential PV plant on the housing market to maximize their cost-benefit trade-offs and implement cost-effective investment strategies.

The remainder of the paper is structured as follows. Section 2 reports a literature review on studies that are focused on market price premium estimation for solar homes; in Section 3, the survey design and the methodology adopted are described; in Section 4, results are presented and discussed; Section 5 provides main conclusions.

\section{Related Literature}

There is flourishing literature in the US focusing on the impacts of residential PV plants on real estate markets. The most relevant contributions with respect to ours are synthesized in what follows.

Ref. [17] implemented the hedonic price method and the repeat sales approach to investigate whether solar homes in the San Diego and Sacramento areas (California) exhibit higher sale transaction prices than homes that are not equipped with a PV plant. According to their findings, the market price premium for solar homes ranged between $3 \%$ and $4 \%$. Higher price premiums are observed in communities featuring large shares of college graduates and a vast number of registered Prius hybrid vehicles [17].

Ref. [27] estimated the marginal impact of PV plants on real estate sale prices in California. A hedonic pricing model was implemented on a large dataset of home sale transactions, approximately 72,000 observations, registered in 2000-2009. The estimated market prices for solar homes ranged from USD/W 3.9 to USD/W 5.8. This evidence on a market price premium was confirmed by [29], who examined 22,822 home sales in eight US states in the period 2002-2013. They found that homebuyers are willing to pay average premiums across the sample equal to USD 15,000 (i.e., USD/W 4) for an average-sized $3.6 \mathrm{~kW}$ PV plant.

Ref. [30] investigated the effect of the visual appeal of PV panels on consumers' preference for residential PV panels. They administered two surveys to US residents, the former of which focused on solar panels' appearance (i.e., surface pattern, color, and frame typology). In contrast, the latter focused on the trade-offs between panels, purchase price, and functional performance. Their results reveal that panels' appearance is relevant: individuals prefer black panels and solar cells with rounded corners and even surfaces. They are willing to pay higher prices for PV plants with a better-looking aesthetical appearance.

Ref. [31] analyzed the impact of domestic solar energy systems on real estate market prices in Arizona. They estimated the market price premium generated by analyzing a dataset of 26,335 single houses listed for sale in Phoenix (Arizona). According to their findings, the average premium for a solar home is about USD 45,000, which at a median home value is equal to $15 \%$. In addition, the transaction sales price premium is coincident with a $17 \%$ increase at medium sales price.

Ref. [32] estimated people's WTP for installing domestic PV plants in Eindhoven (the Netherlands). Due to the lack of real market data, they implemented a DCE based on responses of 227 homebuyers. Their results show that homebuyers' preferences are significant: PV systems exhibit the second-largest positive impact on the choice of dwellings, PV systems are more appealing to home buyers in urban or central neighborhoods of Eindhoven, and only $4 \%$ of respondents appreciate the aesthetic appearance of PV plants. In addition, [32] measured the WTP for solar homes by direct surveying via an open-ended question format. Their findings reveal that, on average, respondents are willing to pay a price premium of EUR 5370 (in line with the PV system replacement value) for solar homes. In contrast, only $22 \%$ of respondents are not willing to pay any price premium.

Ref. [33] adopted an adaptive choice-based conjoint approach to investigate the key drivers influencing homeowners' preferences for domestic rooftop PV plants in Switzer- 
land. Their results show that the country of origin and the color of PV modules were the most important key drivers that attract homeowners' investments. In addition, they estimated that homeowners are willing to pay a premium of $21.79 \%$ for building-integrated $\mathrm{PV}$ installation compared to a rack-mounted PV installation, confirming that aesthetic appearance matters.

Ref. [13] conducted an open-ended contingent valuation study in Italy to estimate the market price premium for a detached house equipped with two different PV plants, constituted by monocrystalline and polycrystalline panels, respectively, but the same installed power equal to $3 \mathrm{kWp}$. Their findings indicate that WTP ranges from about EUR 4500 to EUR 6300 for monocrystalline and polycrystalline PV plants, respectively. The relative average market price premiums are equal to $2.69 \%$ and $3.08 \%$, respectively.

Among the above contributions, the closest to ours is [13]. Nonetheless, differently from [13] and to complement their analysis, in this paper in line with [32] and [33], we implement a DCE to account via more sophisticated modeling for the impact of different attributes of PV plants on solar homes market price premium.

\section{Materials and Method}

\subsection{Method}

Due to the lack of real market data, a survey was conducted to collect stated preference data. Consequently, actual behavior was not observed, but respondents were requested to make choices based on several choice tasks, each containing hypothetical choice alternatives [38]. It is commonly agreed that individuals' choices reflect their preferences over different alternatives of goods and services [39]. A set of attributes characterized each choice alternative, and each attribute assumed one of several levels that described ranges of attribute variation across choice alternatives $[38,40]$.

Based on random utility theory assumptions [41-43], let us posit that the utility $\boldsymbol{U}_{i k t}$ perceived by the respondent $i$ for a given alternative $k$ in the choice task $t$ is a function of $S$ attributes, which characterize the $\boldsymbol{k}-\boldsymbol{t} \boldsymbol{h}$ alternative as follows:

$$
U_{i k t}=V_{i k t}+\varepsilon_{i t k}
$$

where $V_{i k t}$ is the representative utility formulated by the researcher and $\varepsilon_{i t k}$ is the error term, which captures factors that affect utility $\boldsymbol{U}_{i k t}$, but are not included in $\boldsymbol{V}_{\boldsymbol{i k t}}$ [44]. $\boldsymbol{V}_{\boldsymbol{i k t}}$ is usually linear in parameters:

$$
V_{i k t}=\sum_{s=1}^{S} \beta_{s} x_{s i t k}
$$

where $x_{\text {sitk }}$ is a vector of attributes, which defines the representative utility function and $\beta_{s}$ is the marginal utility of the $s-\boldsymbol{t} \boldsymbol{h}$ attribute. Under the assumption that $\varepsilon_{i t k}$ follows a type I extreme value distribution, the probability $\boldsymbol{P}_{i k t}$ that respondent $i$ selects choice alternative $k$ in choice task $t$ is expressed in the multinomial logit model (MNL) as follows:

$$
P_{i k t}=\frac{e^{\sum_{s=1}^{S} \beta_{s} x_{s i k t}}}{\sum_{j} e^{\sum_{s=1}^{S} \beta_{s} x_{s i j t}}}
$$

The marginal utility coefficients $\beta_{s}$ are estimated by maximizing the log-likelihood function [45]:

$$
L L(\beta)=\sum_{i=1}^{N} \sum_{t=1}^{T} \sum_{k=1}^{K} y_{i t k} \ln \left(P_{i k t}\right)=\sum_{i=1}^{N} \sum_{t=1}^{T} \sum_{k=1}^{K} y_{i t k} \ln \left(\frac{e^{\sum_{s=1}^{S} \beta_{s} x_{s i k t}}}{\sum_{j} e^{\sum_{s=1}^{S} \beta_{s} x_{s i j t}}}\right)
$$

where $N$ is the total number of respondents, $T$ is the number of choice tasks, which contain $K$ choice alternatives, $y_{i t k}$ is a dummy variable that assumes the value of 1 if respondent $i$ selects alternative $\mathrm{k}$ in the choice task $t$. A cost attribute, whose marginal coefficient is denoted by $\beta_{\text {cost }}$ is inserted in the formulation of the representative utility 
function $V_{i k t}$ to estimate the marginal WTP related to each $s$-th attribute $(s=1, \ldots, S ; s \neq c)$. The marginal WTP of the $s$-th attribute $\boldsymbol{m} W \mathbf{T P}_{\boldsymbol{s}}$ is thus estimated as follows $[40,46,47]$ :

$$
m W T P_{s}=-\frac{\beta_{s}}{\beta_{\text {cost }}}
$$

For the purpose of our study, the representative utility function $V_{i k t}$ is grounded into two attributes: the former is related to the PV plant typology, and the latter is the cost attribute, coincident with the asset's hypothetical (contingent) market price. To estimate the marginal WTP for each PV plant typology, attribute levels related to the PV plant typology are dummy coded. The attribute level "NO PV plant" is chosen as the reference level, and thus, its coefficient is set equal to zero $[40,48]$. The representative utility function is:

$$
\begin{gathered}
V=a s c+\beta_{p l_{1}} d_{p l_{1}}+\beta_{p l_{2}} d_{p l_{2}}+\beta_{p l_{3}} d_{p l_{3}}+\beta_{p l_{4}} d_{p l_{4}} \\
+\beta_{p l_{-} 5} d_{p l_{-} 5}+\beta_{\text {cost }} X_{\text {cost }}
\end{gathered}
$$

where $\boldsymbol{a s c}$ is the alternative-specific constant of the representative utility function, $\beta_{p l \_1}, \beta_{p l \_2}$ $\beta_{p l_{-} 3}, \beta_{p l_{-} 4}, \beta_{p l_{-} 5}$ are the coefficients of the dummy coded attribute levels, $d_{p l_{-} 1}, d_{p l \_2}, d_{p l \_3}$, $d_{p l \_4}, d_{p l \_5}$ are the PV-plant-typology attribute levels, dummy coded, $\beta_{\text {cost }}$ is the cost coefficient, and $\boldsymbol{X}_{\text {cost }}$ is the cost attribute.

The experimental design procedure is then implemented to create the choice tasks by combining PV-plant-typology attribute levels and cost attribute levels [40]. In detail, it adopted the efficient design methodology, which ensures the statistical significance of parameter estimates by simultaneously reducing the sample size to the minimum as possible [49-54]. Using the NGENE software, 9 choice tasks were obtained, and the minimum sample size of 80 respondents has been estimated.

\subsection{Survey Design and Administration}

Our survey aimed to investigate the effect of PV plants' different technical characteristics on WTP and elicit the WTP for domestic rooftop PV plants for solar homes. In this DCE respondents played the role of the homebuyers of a hypothetical building and faced a set of nine choice tasks. Each choice task involved choosing among two choice alternatives, which refers to the hypothetical building equipped or not with different typologies of PV panels. For each PV plant typology, the WTP was estimated in terms of the additional price (i.e., the market price premium) that homebuyers are willing to pay for solar homes compared to homes not equipped with PV plants. As in [13], the hypothetical building is a $200 \mathrm{~m}^{2}$ detached house with a private garden, built in the $90 \mathrm{~s}$. This is one of Italy's most widespread building typologies [55,56], and the asset current market price is EUR 200,000.

We accounted for two attributes: "PV plant typology" and "cost."

For attribute "PV plant typology," we considered six attribute levels, namely the absence of PV plant and five different plant typologies (Table 1). The five PV plants under investigation differed in terms of technical characteristics, such as solar cells typology (i.e., monocrystalline, monocrystalline total black and polycrystalline panels), PV plant surface (i.e., 13, 16, 22, and $26 \mathrm{~m}^{2}$ ), installed power (i.e., 3 and $5 \mathrm{kWp}$ ) and installation typology (rooftop-integrated and rack-mounted PV plants). The relative rate of $\mathrm{CO}_{2}$ emissions reduction and cost savings for each PV plant were estimated (Table 2). It is worth noting that the PV plant selection was discussed in a focus group with a panel of experts (e.g., academics, engineers, and PV plants' suppliers). 
Table 1. Attribute "PV plant typology" levels.

\begin{tabular}{cc}
\hline Attribute Levels \\
\hline NO PV plant \\
PV plant \#1 \\
PV plant \#2 \\
PV plant \#3 \\
PV plant \#4 \\
PV plant \#5 \\
\hline
\end{tabular}

Table 2. PV plant typologies and related technical characteristics.

\begin{tabular}{|c|c|c|}
\hline PV Plant & Technical Characteristics & \\
\hline \multirow{7}{*}{ PV plant \#1 } & Solar cells typology & Polycrystalline \\
\hline & Efficiency & $19 \%$ \\
\hline & PV plant surface $\left[\mathrm{m}^{2}\right]$ & 16 \\
\hline & Installation mode & Rack-mounted \\
\hline & Annual energy savings in monetary terms [ $€$ /year] & 400 \\
\hline & Annual $\mathrm{CO}_{2}$ emissions reduction $[\mathrm{kg} /$ year $]$ & 1910 \\
\hline & Installed power $[\mathrm{kWp}]$ & 3 \\
\hline \multirow{7}{*}{ PV plant \#2 } & Solar cells typology & Monocrystalline \\
\hline & Efficiency & $23 \%$ \\
\hline & PV plant surface $\left[\mathrm{m}^{2}\right]$ & 13 \\
\hline & Installation mode & Rooftop-integrated \\
\hline & Annual energy savings in monetary terms [ $€$ /year] & 400 \\
\hline & Annual $\mathrm{CO}_{2}$ emissions reduction $[\mathrm{kg} /$ year $]$ & 1910 \\
\hline & Installed power $[\mathrm{kWp}]$ & 3 \\
\hline \multirow{7}{*}{ PV plant \#3 } & Solar cells typology & Total black \\
\hline & Efficiency & $23 \%$ \\
\hline & PV plant surface $\left[\mathrm{m}^{2}\right]$ & 13 \\
\hline & Installation mode & Rooftop-integrated \\
\hline & Annual energy savings in monetary terms [ $€ /$ year] & 400 \\
\hline & Annual $\mathrm{CO}_{2}$ emissions reduction $[\mathrm{kg} /$ year $]$ & 1910 \\
\hline & Installed power $[\mathrm{kWp}]$ & 3 \\
\hline \multirow{7}{*}{ PV plant \#4 } & Solar cells typology & Polycrystalline \\
\hline & Efficiency & $19 \%$ \\
\hline & PV plant surface $\left[\mathrm{m}^{2}\right]$ & 26 \\
\hline & Installation mode & Rooftop-integrated \\
\hline & Annual energy savings in monetary terms [ $€$ /year] & 550 \\
\hline & Annual $\mathrm{CO}_{2}$ emissions reduction $[\mathrm{kg} /$ year $]$ & 3180 \\
\hline & Installed power $[\mathrm{kWp}]$ & 5 \\
\hline \multirow{7}{*}{ PV plant \#5 } & Solar cells typology & Polycrystalline \\
\hline & Efficiency & $19 \%$ \\
\hline & PV plant surface $\left[\mathrm{m}^{2}\right]$ & 26 \\
\hline & Installation mode & Rack-mounted \\
\hline & Annual energy savings in monetary terms [ $€$ /year] & 550 \\
\hline & Annual $\mathrm{CO}_{2}$ emissions reduction $[\mathrm{kg} /$ year $]$ & 3180 \\
\hline & Installed power $[\mathrm{kWp}]$ & 5 \\
\hline
\end{tabular}

In the contingent scenario, the levels of attribute "cost" represent the asset hypothetical market price and relative market price premium regarding the hypothetical building if not equipped with PV panels. The levels of attribute "cost" were selected according to [13]. They estimated the building's market price premium in terms of respondents' WTP for different PV plants by implementing an open-ended format in a contingent valuation study. They were seven cost attribute levels, and they were selected based on literature, [13]'s findings, and discussion with the panel of experts [40]. The lowest cost attribute level corresponds to the current market price of the hypothetical building equal to EUR 200,000; 
consequently, the lowest market price premium is equal to $0 \%$. This cost attribute level accounts for the event that respondents are not willing to pay an additional price for a solar home, ceteris paribus. The cost attribute levels are reported in Table 3 and the market price premiums ranges from $3 \%$ to $25 \%$ (i.e., $3 \%, 5 \%, 7 \%, 13 \%, 18 \%$, and $25 \%$ ). The highest market price premium (i.e., 25\%) accounts for the growing interest manifested by Italian residents in investing in domestic PV plants [14], which is expected to increase further in the near future [57]. The above price premiums are in line with the literature, especially relative to the US context, where real market data are available, and the capitalization effect of cost savings due to PV self-consumption is robustly proven [29-31].

Table 3. Cost attribute levels.

\begin{tabular}{cc}
\hline Market Price [EUR] & Price Premium for the Solar Home \\
\hline 200,000 & $0 \%$ \\
206,000 & $3 \%$ \\
210,000 & $5 \%$ \\
214,000 & $7 \%$ \\
226,000 & $13 \%$ \\
236,000 & $18 \%$ \\
250,000 & $25 \%$ \\
\hline
\end{tabular}

The survey questionnaire was structured into five sections. In Section 1, the research topic and aim are introduced to respondents to increase their knowledge on PV plants and their engagement in the survey and motivate the research. Some information about the effects of climate change and GHG emissions related to energy consumption is presented. The 2030 and 2050 European targets for the mitigation of climate change are briefly described. In addition, respondents are informed that renewables, such as PV solar energy, are a key factor in the energy transition from fossil fuels to renewables and the benefits generated by PV production (e.g., GHG emission reduction, cost savings due to self-consumption, etc.) are listed such as GHG emissions reduction and energy cost savings on energy bills due to self-consumption. In Section 2, the valuation scenario is presented, and a rendering of the detached house and a detailed description of the asset's characteristics are provided (Figure 1).

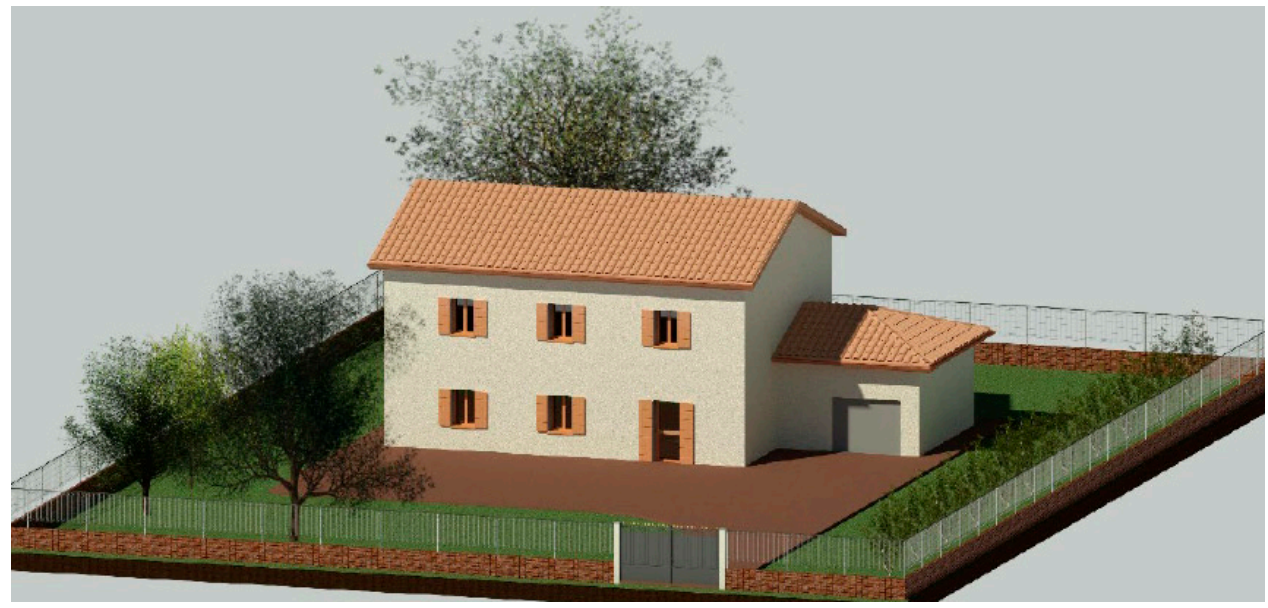

Figure 1. Rendering of the reference building (source: our processing from [13]).

In Section 3, the contingent scenario and the PV plant typologies under investigation are illustrated. In detail, it is explained to respondents that they have to play the role of a homebuyer of the hypothetical detached house. In each choice task, they have to choose among a set of two alternatives, in which the typology of installed PV plants (including the absence of any PV plant) and the building's market price vary. 
In Section 4, instructions to compile the survey and choice tasks are presented (Figure 2). Finally, in Section 5, respondents' sociodemographic characteristics are collected (gender, age, educational attainment, and individual annual income).

\begin{tabular}{|c|c|c|}
\hline & ALTERNATIVE 1 & ALTERNATIVE 2 \\
\hline CHOICE TASK 1 & & \\
\hline PV plant typology & $\begin{array}{c}\text { Polycrystalline } \\
\text { Efficiency: } 19 \% \\
\text { Surface: } 16 \mathrm{~m}^{2} \\
\text { Rack-mounted } \\
\text { Annual energy savings: } \\
400 \mathrm{EUR} / \text { year } \\
\text { Annual } \mathrm{CO}_{2} \text { emissions } \\
\text { reduction }: 1910 \mathrm{~kg} / \text { year } \\
\text { Installed power } 3 \mathrm{kWp}\end{array}$ & $\begin{array}{c}\text { Total black } \\
\text { Efficiency: } 23 \% \\
\text { Surface: } 13 \mathrm{~m}^{2} \\
\text { Roof-top integrated } \\
\text { Annual energy savings: } \\
400 \mathrm{EUR} / \text { year } \\
\text { Annual } \mathrm{CO}_{2} \text { emissions } \\
\text { reduction }: 1910 \mathrm{~kg} / \text { year } \\
\text { Installed power } 3 \mathrm{kWp}\end{array}$ \\
\hline Cost & EUR 220,000 & EUR 236,000 \\
\hline
\end{tabular}

Figure 2. Example of choice task.

The survey was self-administered by computer-assisted web interviewing (CAWI) and was conducted from October 2020-November 2020. The sample was randomly selected by a survey company, which stratified the sample based on the most relevant socio-demographics (e.g., gender, age, educational attainment, and income) related to the 2011 Italian census, and the questionnaire was administered to 400 Italian residents, aged between 18 and 70 years. Finally, a set of 240 fully filled questionnaires was collected and examined.

\section{Results and Discussion}

Descriptive statistics of the sample are reported in Table 4.

Table 4. Descriptive statistics of the sample.

\begin{tabular}{|c|c|c|}
\hline \multicolumn{2}{|c|}{ Variable } & \multirow{3}{*}{$\begin{array}{c}\text { \% } \\
47.02 \% \\
52.98 \%\end{array}$} \\
\hline & $\mathrm{M}$ & \\
\hline Gender & $\mathrm{F}$ & \\
\hline \multirow{5}{*}{ Age } & $18-29$ & $22.84 \%$ \\
\hline & $30-39$ & $10.58 \%$ \\
\hline & $40-49$ & $15.34 \%$ \\
\hline & $50-59$ & $16.47 \%$ \\
\hline & $60-70$ & $34.77 \%$ \\
\hline \multirow{4}{*}{ Educational Attainment } & Middle school diploma & $5.56 \%$ \\
\hline & High school diploma & $35.38 \%$ \\
\hline & Bachelor degree & $50.24 \%$ \\
\hline & Master degree/PhD & $8.82 \%$ \\
\hline \multirow{5}{*}{ Individual Annual Income } & 0-15,000 EUR & $34.35 \%$ \\
\hline & $15,001 €-28,000 \mathrm{EUR}$ & $37.13 \%$ \\
\hline & $28,001 €-55,000 \mathrm{EUR}$ & $23.61 \%$ \\
\hline & 55,001 €-75,000 EUR & $2.80 \%$ \\
\hline & $>75,000$ EUR & $2.11 \%$ \\
\hline
\end{tabular}

Some $47 \%$ of respondents were male, and $53 \%$ were female. Some $23 \%$ of respondents were aged between 18 and 29 years, $10.58 \%$ of respondents were aged between 
30 and 39 years, 15\% were aged between 40 and 49 years, $16.47 \%$ aged between 50 and 59 years, whereas respondents aged 60 years or more accounted for $34.77 \%$. Some $6 \%$ of interviewees have a middle school diploma, $35.38 \%$ have a high school diploma, and $50.24 \%$ have a bachelor's degree, whereas some $9 \%$ of the sample have a master's degree or a Ph.D. As to age and educational attainment, the sample reflects population shares in the country $[58,59]$. Some $34 \%$ of respondents reported an individual annual income lower than EUR 15,000, some 37\% reported an individual annual income ranging between EUR 15,001 and EUR 28,000, 23.61\% of respondents declared an individual annual income, which ranges EUR 28,001 and EUR 55,000, whereas 4.91\% report an individual annual income greater than EUR 55,000 (of which 2.11\% greater than EUR 75,000). These figures mirror individual annual income shares in the country [60].

Model estimates were performed using Apollo R-package (Table 5).

Table 5. Model estimates.

\begin{tabular}{|c|c|c|c|}
\hline Coefficient & Estimate & Standard Error & t-Value \\
\hline$\beta_{p l \_1}$ & 0.3065 & 0.1497 & $2.04^{* * *}$ \\
\hline$\beta_{p l \_2}$ & 0.8463 & 0.2898 & $2.92 * * * *$ \\
\hline$\beta_{p l \_3}$ & 0.9178 & 0.2776 & $3.31^{* * * *}$ \\
\hline$\beta_{p l \_}$ & 1.4963 & 0.3828 & $3.91^{* * * *}$ \\
\hline$\beta_{p l \_5}$ & 1.4897 & 0.512 & $3.10 * * * *$ \\
\hline \multicolumn{4}{|c|}{ NO PV plant: Reference level (set to 0) } \\
\hline$\beta_{\text {cost }}$ & -0.4936 & 0.096 & $-5.14^{* * * *}$ \\
\hline asc & -0.3691 & 0.1462 & $-2.52 * * * *$ \\
\hline
\end{tabular}

From direct inspection of Table 5, it emerges that estimated coefficients are statistically significant (i.e., $\alpha=5 \%$ ). According to our findings, PV plant typology \#4 is the most appreciated $\left(\beta_{p l \_}=1.4963\right)$, whereas PV plant typology \#1 is the least appreciated $\left(\beta_{p l \_1}=0.3065\right)$. All the estimated coefficients $\beta_{p l}$ are positive. This suggests that individuals perceive an increase in their utility level due to solar technologies, and consequently, they are willing to pay for solar homes.

Equation (5) mWTP for each PV plant typology was estimated, and subsequently, to compare results with literature findings, the relative market price premiums have been computed (Table 6).

Table 6. WTP figures for different PV plant typologies.

\begin{tabular}{ccc}
\hline PV Plant Typology & mWTP [EUR] & Price Premium [\%] \\
\hline PV plant \#1 & 6209 & $3.10 \%$ \\
PV plant \#2 & 17,145 & $8.57 \%$ \\
PV plant \#3 & 18,594 & $9.30 \%$ \\
PV plant \#4 & 30,314 & $15.16 \%$ \\
PV plant \#5 & 30,180 & $15.09 \%$ \\
\hline
\end{tabular}

From direct inspection of Table 6, it can be easily shown that PV plant typology \#4 exhibits the highest mWTP (i.e., EUR 30,314). In contrast, the minimum mWTP (i.e., EUR 6209) was related to PV plant typology \#1. In percentage terms, estimated market price premiums ranged from $3.10 \%$ to $15.16 \%$ for PV plant typology \#1 and PV plant typology \#2, respectively. These results were in line with the existing literature, according to which market price premiums for solar homes vary in the range of 3-15\% [13,17,31]. Generally speaking, the greater the installed power, the higher the individuals' willingness to pay: the WTPs for PV plant typology \#4 and \#5 were the highest (i.e., EUR 30,314 and EUR 30,180, respectively). It is worth noting that the higher the installed power, the higher the energy cost saving (e.g., the mWTP for PV plant typology \#5 was higher than the mWTP for PV plant typology \#1). Consequently, individuals do care about panels' 
energy performance and potential energy savings. In addition, rooftop-integrated panels are preferred to some extent to rack-mounted PV panels, energy savings being equal (e.g., EUR 30,314 vs. EUR 30,180 for PV plant typology \#4 and \#5, respectively).

Responses to follow-up questions confirmed these results. Respondents were asked to rank from most to least preferred the following characteristics of the attribute "PV plant typology": solar cells typology, installation mode, annual energy (costs) saving, and annual $\mathrm{CO}_{2}$ emission reduction. According to these responses, the most valued characteristic of PV panels was energy efficiency. It generated cost savings (ranked as first by some $67 \%$ of respondents). In contrast, the plant's aesthetic appearance associated with the panels' mode of installation (rooftop-integrated vs. rack-mounted) is of minor relevance in terms of preferences, ceteris paribus. Surprisingly, GHG emission reduction is not considered of major importance (ranked as last by some $52 \%$ of respondents), thereby revealing that environmental awareness is still limited compared to Government's expectations, and information campaigns are still necessary. Finally, panel color was considered of negligible importance (i.e., black panels are not perceived as a significant technological improvement).

\section{Conclusions}

PV generation in Italy has rapidly grown in the last decades due to generous incentive schemes introduced by the Government starting from 2012. When introduced, these incentives favored investments and made PV plants attractive for small private investors in the residential sector. Although still limited due to the lack of market data on sales transactions of solar homes, which are expected to enter the market more consistently in the near future, there is evidence in the literature that the wealth of economic and environmental benefits generated by solar technologies and PV energy production are capitalized into solar homes market prices. As this lack of data is most challenging in Italy than elsewhere in the EU, to contribute to the extremely scarce literature focusing on the market price premium for solar homes, we implemented a DCE approach and estimated individuals' WTP for different typologies of domestic PV plants, which vary in technical characteristics. The market price premium for solar homes was then calculated to verify whether solar homes sell for more compared to homes not equipped with PV plants. Our results reveal that individuals are willing to pay higher prices for solar homes compared to homes not equipped with PV plants, ceteris paribus. The estimated market price premiums are coherent with international literature findings and range from some $3 \%$ to some $15 \%$. The percentages are in line with other similar studies conducted in the literature. According to our findings, the greater the installed power, the greater the WTP, and the minor the perceived impact of the panels on the aesthetic appearance of the building, the greater the WTP. Responses to follow-up questions confirm that individuals value the most monetary savings generated by energy self-consumption; by contrast, GHG emission reduction attributable to PV generation is not considered of major importance.

Our results can have interesting implications for both real estate investors and policymakers. As to the former, due to the capitalization effect of PV generation and increasing environmental awareness, PV plants can positively impact the demand for second-hand houses and affect real estate market returns. As to the latter, our findings can inform policy incentive design, thereby avoiding introducing excessively costly incentive schemes for society as a whole. In the case at hand, the issue of optimal incentive design to RES, in general, and PV energy is ever more challenging nowadays. The overarching goal of the European Green Deal of making Europe climate neutral by 2050 is de facto posing PV production at the core of a fast energy transition in many EU countries.

The limitations of our DCE are common to stated preference methods. Hypothetical bias is often a documented limitation in DCEs. Respondents may de facto assume a strategic behavior in expressing WTP values in contingent markets, and consequently, elicited WTPs may be higher than those observed in regular marketplaces. This issue is largely debated in the literature. The definition of a credible choice scenario on a welldefined good combined with an efficient survey design has proven to reduce hypothetical 
bias. In addition, estimates based on stated preference data call for considering the tradeoffs between the uses of parsimonious vs. more complex models carefully. In this respect, the Multinomial Logit Model implemented here does not account for heterogeneity in preferences, which are unrelated to observed characteristics.

Nonetheless, regardless of the limitations mentioned above, DCEs have been successfully implemented when there is a lack of observations on market transactions under the desired conditions. Compared to other stated preference methods, DCEs encourage respondents to focus on the trade-offs between different characteristics of the good under investigation. According to a precautionary approach to real estate appraisal, it is reasonable to assume that our estimated market price premiums for solar homes may represent an upper bound of sale transaction prices.

Future research will include implementing a mixed multinomial logit model to capture the heterogeneity of preferences and a new survey to test whether WTP figures are affected by buildings typology. It is worth noting that existing literature on the market price premium for solar homes considers rather exclusively detached homes. In this respect, we aim at administering an analogous survey format by varying, nevertheless, the hypothetical building under investigation and assuming it is, e.g., a semi-detached home, or terraced home, or condominium.

Author Contributions: Conceptualization C.D.; Methodology P.B., C.D.; Analysis of model results P.B., C.D.; Validation P.B., C.D.; Writing of the original draft P.B., C.D.; Writing revised versions \& editing C.D.; Supervision and Funding acquisition C.D. Both authors have read and agreed to the published version of the manuscript.

Funding: This research was funded by Interdepartmental Centre "Giorgio Levi Cases", grant number 2020LC07.

Data Availability Statement: Data available on request.

Conflicts of Interest: The authors declare no conflict of interest.

\section{References}

1. European Commission. 2021. Available online: https://ec.europa.eu/energy/topics/renewable-energy/renewable-energydirective/overview_it\#the-recast-directive-2018-2001-eu (accessed on 9 June 2021).

2. Mancò, G.; Guelpa, E.; Colangelo, A.; Virtuani, A.; Morbiato, T.; Verda, V. Innovative renewable technology integration for nearly zero-energy buildings within the Re-cognition project. Sustainability 2021, 13, 1938. [CrossRef]

3. Barron-Gafford, G.A.; Minor, R.L.; Allen, N.A.; Cronin, A.D.; Brooks, A.E.; Pavao-Zuckerman, M.A. The Photovoltaic Heat Island Effect: Larger solar power plants increase local temperatures. Sci. Rep. 2016, 6, 35070. [CrossRef]

4. Torlo, M.; Kreso, I.; Edin, Š. Renewable Energy Sources in Construction of Energy Efficient Residential Buildings. In Lecture Notes in Networks and Systems; Springer: Berlin/Heidelberg, Germany, 2020; Volume 128, pp. 709-719.

5. Colak, H.E.; Memisoglu, T.; Gercek, Y. Optimal site selection for solar photovoltaic (PV) power plants using GIS and AHP: A case study of Malatya Province, Turkey. Renew. Energy 2020, 149, 565-576. [CrossRef]

6. Li, R.; Leung, G.C.K. The relationship between energy prices, economic growth and renewable energy consumption: Evidence from Europe. Energy Rep. 2021, 7, 1712-1719. [CrossRef]

7. Fratini, P.; Moretti, E.; Belloni, E. Energy and economic evaluation of solar photovoltaics plants: Influence of different input parameters. In Proceedings of the ECOS 2012-The 25th International Conference on Efficiency, Cost, Optimization, Simulation And Environmental Impact Of Energy Systems, Perugia, Italy, 26-29 June 2012.

8. Mangan, S.D.; Koçlar Oral, G. Energy, economic and environmental analyses of photovoltaic systems in the energy renovation of residential buildings in Turkey. A/Z ITU J. Fac. Arch. 2016, 13, 5-22. [CrossRef]

9. Akter, M.N.; Mahmud, M.A.; Amanullah, M.T.O. Comprehensive economic evaluations of a residential building with solar photovoltaic and battery energy storage systems: An Australian case study. Energy Build. 2017, 138, 332-346. [CrossRef]

10. Minuto, F.D.; Lazzeroni, P.; Borchiellini, R.; Olivero, S.; Bottaccioli, L.; Lanzini, A. Modeling technology retrofit scenarios for the conversion of condominium into an energy community: An Italian case study. J. Clean. Prod. 2021, 282, 124536. [CrossRef]

11. Bertolini, M.; D'Alpaos, C.; Moretto, M. Do Smart Grids boost investments in domestic PV plants? Evidence from the Italian electricity market. Energy 2018, 149, 890-902. [CrossRef]

12. D'Alpaos, C.; Moretto, M. Do Smart grid innovations affect real estate market values? AIMS Energy 2019, 7, 141-150. [CrossRef]

13. D'Alpaos, C.; Bragolusi, P. The market price premium for residential PV plants. In Smart Innovation, Systems and Technologies; Springer: Berlin/Heidelberg, Germany, 2021; Volume 178, pp. 1208-1216. [CrossRef] 
14. Gestore Servizi Energetici (GSE). 2020. Available online: https://www.gse.it/documenti_site/Documenti\%20GSE/Rapporti\%20 statistici/Solare\%20Fotovoltaico\%20-\%20Rapporto\%20Statistico\%202019.pdf (accessed on 15 June 2021).

15. Abdelhafez, M.H.H.; Touahmia, M.; Noaime, E.; Albaqawy, G.A.; Elkhayat, K.; Achour, B.; Boukendakdji, M. Integrating solar photovoltaics in residential buildings: Towards zero energy buildings in hail city, ksa. Sustainability 2021, $13,1845$.

16. Hu, X.; Xiang, Y.; Zhang, H.; Lin, Q.; Wang, W.; Wang, H. Active-passive combined energy-efficient retrofit of rural residence with non-benchmarked construction: A case study in Shandong province, China. Energy Rep. 2021, 7, 1360-1373. [CrossRef]

17. Dastrup, S.R.; Graff Zivin, J.; Costa, D.L.; Kahn, M.E. Understanding the Solar Home price premium: Electricity generation and "Green" social status. Eur. Econ. Rev. 2012, 56, 961-973. [CrossRef]

18. Kok, N.; Miller, N.G.; Morris, P. The Economics of Green Retrofits. J. Sustain. Real Estate 2011, 4, 4-22. [CrossRef]

19. Kahn, M.E.; Kok, N. The capitalization of green labels in the California housing market. Reg. Sci. Urban Econ. 2014, 47, 25-34. [CrossRef]

20. Dell'Anna, F.; Bravi, M.; Marmolejo-Duarte, C.; Bottero, M.C.; Chen, A. EPC green premium in two different European climate zones: A comparative study between Barcelona and Turin. Sustainability 2019, 11, 5605. [CrossRef]

21. Mangialardo, A.; Micelli, E.; Saccani, F. Does sustainability affect real estate market values? Empirical evidence from the office buildings market in Milan (Italy). Sustainability 2018, 11, 12. [CrossRef]

22. Chegut, A.; Eichholtz, P.; Kok, N. The price of innovation: An analysis of the marginal cost of green buildings. J. Environ. Econ. Manag. 2019, 98, 102248. [CrossRef]

23. Stanley, S.; Lyons, R.C.; Lyons, S. The price effect of building energy ratings in the Dublin residential market. Energy Efficiency 2016, 9, 875-885. [CrossRef]

24. Papineau, M. Energy Efficiency Premiums in Unlabeled Office Buildings. Energy J. 2017, 38, 195-212. [CrossRef]

25. Zhang, L.; Liu, H.; Wu, J. The price premium for green-labelled housing: Evidence from China. Urban Studies 2017, 54, 3524-3541. [CrossRef]

26. Lee, H.; Lee, M.; Lim, S. Do Consumers Care about the Energy Efficiency of Build-ings? Understanding Residential Choice Based on Energy Performance Certificates. Sustainability 2018, 10, 4297. [CrossRef]

27. Hoen, B.; Wiser, R.; Thayer, M.; Cappers, P. Residential photovoltaic energy systems in California: The effect on home sales prices. Contemp. Econ. Policy 2013, 31, 708-718. [CrossRef]

28. Desmarais, L. The Impact of Photovoltaic Systems on Market Value and Marketability: A Case Study of 30 Single-Family Homes in the North and Northwest Denver Metro Area. 2013. Available online: https:/ /www.colorado.gov/pacific/energyoffice/atom/ 14956 (accessed on 9 June 2021).

29. Hoen, B.; Adomatis, S.; Jacksonc, T.; Graff-Zivin, J.; Thayere, M.; Klise, G.T.; Wiser, R. Multi-state residential transaction estimates of solar photovoltaic system premiums. Renew. Energy Focus 2017, 19-20, 90-103. [CrossRef]

30. Bao, Q.; Honda, T.; El Ferik, S.; Shaukat, M.M.; Yang, M.C. Understanding the role of visual appeal in consumer preference for residential solar panels. Renew. Energy 2017, 113, 1569-1579. [CrossRef]

31. Qiu, Y.; Wang, Y.D.; Wang, J. Soak up the sun: Impact of solar energy systems on residential home values in Arizona. Energy Econ. 2017, 66, 328-336. [CrossRef]

32. Glumac, B.; Wissink, T.P. Homebuyers' preferences concerning installed photovoltaic systems: A discrete choice experiment. J. Eur. Real Estate Res. 2018, 11, 102-124. [CrossRef]

33. Hille, S.L.; Curtius, H.C.; Wüstenhagen, R. Red is the new blue-The role of colour, building integration and country-of-origin in homeowners' preferences for residential photovoltaics. Energy Build. 2018, 162, 21-31. [CrossRef]

34. Baldi, F. Valuing a greenfield real estate property development project: A real options approach. J. Eur. Real Estate Res. 2013, 6, 186-217.

35. Högberg, L. The impact of energy performance on single-family home selling prices in Sweden. J. Eur. Real Estate Res. 2013, 6, 242-261. [CrossRef]

36. Vimpari, J.; Junnila, S. Valuing green building certificates as real options. J. Eur. Real Estate Res. 2014, 7, 181-198. [CrossRef]

37. Rosen, S. Hedonic Prices and Implicit Markets: Product Differentiation in Pure Competition. J. Political Econ. 1974, 82, 34-55. [CrossRef]

38. Lancaster, E.; Louviere, J. Conducting Discrete Choice Experiments to Inform Healthcare Decision Making. Pharmaco Econ. 2008, 26, 661-677.

39. McFadden, D. Conditional logit analysis of qualitative choice behaviour. In Frontiers in Econometrics; Zarembka, P., Ed.; Academic Press: New York, NY, USA, 1974; pp. 105-142.

40. Hanley, N.; Mourato, S.; Wright, R.E. Choice modelling approaches: A superior alternative for environmental valuation? J. Econ. Surv. 2001, 15, 435-462. [CrossRef]

41. Davidson, D. Experimental Tests of a Stochastic Decision Theory (1959). In Economic Information, Decision, and Prediction; Theory and Decision Library (An International Series in the Philosophy and Methodology of the Social and Behavioral Sciences); Springer: Dordrecht, The Netherlands, 1974; Volume 7, pp. 133-171.

42. Manski, C.F. The structure of random utility models. Theory Dec. 1977, 8, 229-254. [CrossRef]

43. Walker, J.; Ben-Akiva, M. Generalized random utility model. Math. Soc. Sci. 2002, 43, 303-343. [CrossRef]

44. Train, K. Discrete Choice Methods with Simulation; Cambridge University Press: New York, NY, USA, 2009; Available online: https:/ / eml.berkeley.edu/books / choice2.html (accessed on 18 January 2021). 
45. Alberini, A.; Ščasný, M.; Bigano, A. Policy-v. individual heterogeneity in the benefits of climate change mitigation: Evidence from a stated-preference survey. Energy Policy 2018, 121, 565-575. [CrossRef]

46. Hanemann, W.M. Welfare evaluations in contingent valuation experiments with discrete responses. Am. J. Agric. Econ. 1984, 66, 332-341. [CrossRef]

47. Parsons, G.R.; Kealy, M.J. Randomly drawn opportunity sets in a random utility model of lake recreation. Land Econ. 1992, 68, 93-106. [CrossRef]

48. Carson, R.T.; Louviere, J.J.; Anderson, D.A.; Arabie, P.; Bunch, D.S.; Hensher, D.A.; Johnson, R.M.; Kuhfeld, W.R.; Steinberg, D.; Swait, J.; et al. Experimental analysis of choice. Mark. Lett. 1994, 5, 351-367. [CrossRef]

49. Huber, J.; Zwerina, K. The importance of utility balance and efficient choice designs. J. Mark. Res. 1996, 33, 307-317. [CrossRef]

50. Kanninen, B.J. Optimal design for multinomial choice experiments. J. Mark. Res. 2002, 39, 214-217. [CrossRef]

51. Rose, J.M.; Bliemer, M.C.J. Designing efficient data for stated choice: Accounting for sociodemographic and contextual effects in designing stated choice experiments. In Proceedings of the 11th International Conference on Travel Behaviour Research, Kyoto, Japan, 16-20 August 2006.

52. Rose, J.M.; Scarpa, R. Designs efficiency for non-market valuation with choice modelling: How to measure it, what to report and why. Aust. J. Agric. Resour. Econ. 2008, 52, 253-282.

53. Rose, J.M.; Bleimer, M.C.J. Constructing Efficient Stated Choice Experimental Designs. Transp. Rev. 2009, 29, 587-617. [CrossRef]

54. Bliemer, M.C.J.; Collins, A.T. On determining priors for the generation of efficient stated choice experimental designs. J. Choice Model. 2016, 21, 10-14. [CrossRef]

55. Istituto Nazionale di Statistica-ISTAT. Edifici E Abitazioni. 2014. Available online: https://www.istat.it/it/files / / 2014/08/Notaedifici-e-abitazioni_rev.pdf (accessed on 9 June 2021).

56. Osservatorio sul Mercato Immobiliare (NOMISMA). 2021. Available online: https://www.nomisma.it/wp-content/uploads/20 21/07/Highlights-2-rapporto-immobiliare-2021.pdf (accessed on 2 August 2021).

57. Agenzia Nazionale Per le Nuove Tecnologie, L'energia e lo Sviluppo Economico Sostenibile (ENEA). 2020. Available online: https://www.enea.it/it/Stampa/news/energia-report-enea-iea-tornano-a-crescere-gli-impianti-fotovoltaici-in-italia (accessed on 9 June 2021).

58. Istituto Nazionale di Statistica (ISTAT). Indicatori Demografici 2019. 2020. Available online: https://www.istat.it/it/files/2020/0 2/Indicatori-demografici_2019.pdf (accessed on 15 June 2021).

59. Istituto Nazionale di Statistica-ISTAT. Indicatori Demografici 2020. 2021. Available online: https://www.istat.it/it/archivio/ indicatori+demografici (accessed on 9 June 2021).

60. Istituto Nazionale di Statistica-ISTAT. Indagine Conoscitiva Sulla Riforma Dell'imposta Sul Reddito delle Persone Fisiche E Altri Aspetti del Sistema Tributario. 2021. Available online: https://www.camera.it/application/xmanager/projects/leg1 8/attachments/upload_file_doc_acquisiti/pdfs/000/004/664/05-bis_Memoria_ISTAT_Allegato_statistico_pdf (accessed on 9 June 2021). 